\title{
An International Comparative Study of Student's Attitude towards Science in Four Asian Countries
}

Azrul Fazwan Kharuddin, Ku Faridah Ku Ibrahim, Zaida Mustafa, Norazura Azid, Darvinatasya Kharuddin

To Link this Article: http://dx.doi.org/10.6007/IJARBSS/v11-i4/9695

DOI:10.6007/IJARBSS/v11-i4/9695

Received: 06 February 2021, Revised: 10 March 2021, Accepted: 31 March 2021

Published Online: 19 April 2021

In-Text Citation: (Kharuddin et al., 2021)

To Cite this Article: Kharuddin, A. F., Ibrahim, K. F. K., Mustafa, Z., Azid, N., \& Kharuddin, D. (2021). An International Comparative Study of Student's Attitude towards Science in Four Asian Countries. International Journal of Academic Research in Business and Social Sciences, 11(4), 479-491.

Copyright: (c) 2021 The Author(s)

Published by Human Resource Management Academic Research Society (www.hrmars.com)

This article is published under the Creative Commons Attribution (CC BY 4.0) license. Anyone may reproduce, distribute, translate and create derivative works of this article (for both commercial and non-commercial purposes), subject to full attribution to the original publication and authors. The full terms of this license may be seen

at: http://creativecommons.org/licences/by/4.0/legalcode

Vol. 11, No. 4, 2021, Pg. 479 - 491

Full Terms \& Conditions of access and use can be found at http://hrmars.com/index.php/pages/detail/publication-ethics 


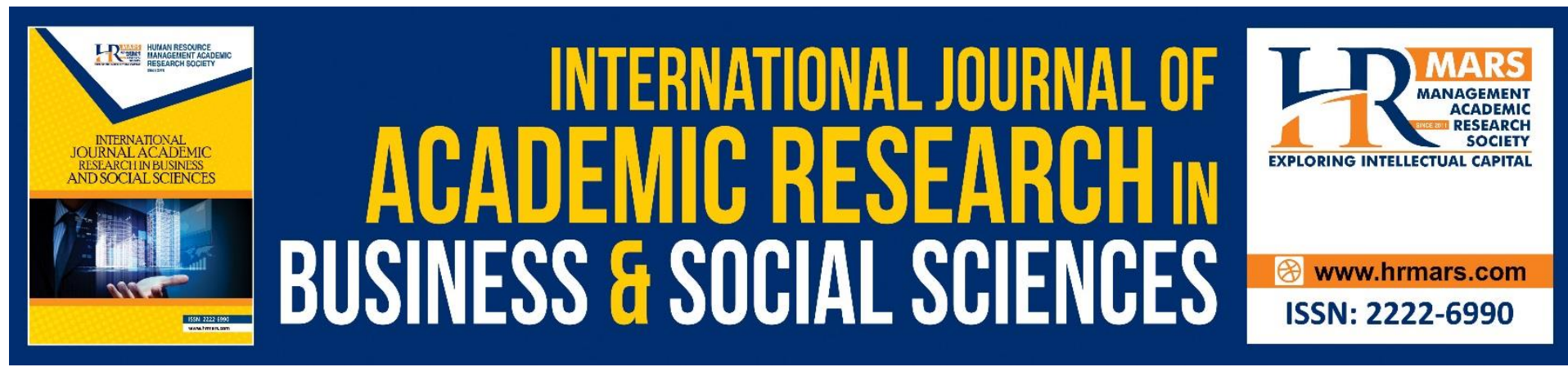

\title{
An International Comparative Study of Student's Attitude towards Science in Four Asian Countries
}

\author{
Azrul Fazwan Kharuddina , Ku Faridah Ku Ibrahim ${ }^{\mathrm{b}}$, Zaida \\ Mustafa $^{\mathrm{b}}$, Norazura Azid ${ }^{\mathrm{c}}$, Darvinatasya Kharuddin ${ }^{\mathrm{d}}$
}

${ }^{a}$ Graduate School of Business, Universiti Tun Abdul Razak, (UNIRAZAK), Malaysia, 'bchool of Education \& Humanities, Universiti Tun Abdul Razak (UNIRAZAK), Malaysia, 'SMK Jeram, Selangor, Malaysia, ${ }^{\mathrm{d}}$ School of Mathematics, Universiti Sains Malaysia (USM), Malaysia

Email: azrulfazwan@unirazak.edu.my

\begin{abstract}
A lot of research has been completed throughout the entire existence of science education to disclosure the angles that support students' performance. Midst these impressions, science student attitude has been unfailingly contemplated. There has regularly been an affiliation initiated between science students' attitude and their performance. Recently, Singaporean and Chinese students have reliably slashed in the top of the cream in science international assessment tests while Malaysian and Thailand students have been put at either flank of the normal imprint. The main objective of this study is in parcel admonished to enlighten why Singaporean and Chinese students seem to do so well in these worldwide comparison. The attitude towards science may assume a key factor of a 14 years old student in four selected nations will be associated. This is an example of students from each country thus mindfulness ought to be applied. There are some astounding discoveries which upon added exploration may have suggestions for arrangement producers and science instructors in Asian countries.
\end{abstract}

Keywords: Science Student, Attitude Towards Science, International Comparison, Science Performance

\section{Introduction}

Various authors (for example Bahamonde, 2017; Schulz et al., 2018; Jung \& Siedlecki, 2018) defined attitude to that attitude is a dormant build, one which is frequently utilized without legitimate definition and should be built up hypothetically. Prendergast and Hongning (2016) established that this is on the grounds that examination on attitude lies at the scholarly junction of a wide range of areas (for example intellectual science, epistemology, arithmetic, brain research, semiotics, human sciences). Anyway despite such run of the mill challenges, there have been a few endeavors at depicting and reclassifying attitude with regards to science training (Hacieminoglu, 2016; Sadruddin, Khawaja \& Zafar, 2017; Widowati, Nurohman \& Anjarsari, 2017; Summers et al., 2019). The attitude theory was presented in the first decades of the $19^{\text {th }}$ century with regards to social science research to predict people's decisions in settings, for example, casting a ballot or purchasing products (Oon \& Fan, 2017). Allport (1935) defined attitude artistically as centers on the impacts of a person's 
psychological practices a particular circumstance. From that point forward, there have been numerous different definitions which center around the idea of attitude as proves by conduct. Notwithstanding the way that there is no standard importance of the term attitude, generally speaking it suggests an insightful tendency or partiality as for an individual to respond quite or antagonistically to some object, condition, thought, or another person (Aiken, 1970). Aiken's description is simple-minded, and accepts a twofold answer (yes or no) to a student's attitude. Mohammad (2016) additionally characterizes attitude comparably; they order attitude as either a positive or negative attitude towards science. In any case the issue with this kind of one-dimensional definition is that it ignores the psychological and brimming with feeling portions of attitude (Hannula, 2002). Ongoing investigation into science student's attitude has shown a noteworthy and close connection among subjective and affective science domains (Miao, Humphrey \& Qian, 2017). Neale (1969) first considered these areas in quite a while meaning of attitude as "a loving or disdaining of science, a propensity to take part in or stay away from science subject exercises, a conviction that one is positive or negative at science, and a conviction that science is helpful or futile". This thought of the multidimensionality of attitude has broadened especially in the last a quarter century. There was a generally perceived interpretation of attitude, feelings and convictions as all having a place with the full of feeling space (for example Mc Leod, 1992; De Bellis \& Goldin, 1997). Anyway Kharuddin and Ismail (2017) decide a three-segment meaning of attitude which segregates belief, effort, and efficacy as segments of attitude characters. This three segment description is recognized social psychology privilege and make reference to a multilateral model, as per which attitude character has a psychological, a full of feeling and a behavioral component (Eagly \& Chaiken, 1998). Regardless of the powerlessness in the implications of attitude there have been an immense volume of studies revealing the augmentation of students' perspectives in the last 25 years. Studies have indicated that, for instance, young ladies will in general have more inspirational attitudes towards science than young men (Caleon \& Subramaniam, 2008), and that perspectives will in general become increasingly positive as students move from primary to secondary school (Astley \& Francis, 2010). Haladyna et al. (1983) briefly explained that the all-inclusive attitude towards science is identified with the nature of the instructing and to the social-psychological environment of the class. Numerous investigations have additionally indicated a connection between students' perspectives towards science and their exhibition in the subject (Ma \& Kishor, 1997; Papanastasiou, 2000). This connection among attitude character and execution is underlined which reasons that science attitude is one of the most significant components influencing interest in cutting edge science subject ( $\mathrm{Ma}, 2001)$. Such a discovering features the significance in further finding out and clarifying the affecting variables on attitude in science training. A few variables have been found to assume a powerful job in the turn of events and improvement of a student's attitude. These incorporate the learning condition, educator quality and important showing strategies (Vernadakis, Avgerinos, Tsitskari \& Zachopoulou, 2005). Mohamed and Waheed (2011) highlighted factors from the society and home environment can likewise be fundamentally influential. For instance numerous research (Dart, Burnett, Purdie, Boulton-Lewis, Campbell \& Smith, 2000; Steiner \& Mendelovitch, 2017) have demonstrated that science students' attitude are related with their folks' view of the subject. This concern can be both either positive or negative. These worries satisfactory with generally held in Asian countries impressed of science as troublesome, cold and dynamic (Woo \& Reeves, 2007). In uniqueness, numerous investigations have discovered that Singaporean guardians have exclusive requirements of their youngsters' presentation in 
science in contrast with their local nations, for example, Malaysia and Thailand (Van ljzendoorn, Juffer \& Poelhuis, 2005). These investigations peak the various ways that guardians from various social foundations can upgrade students' character. Such impacts are associated with family foundation, yet in addition to a greater society. The open picture of science and its notoriety in the public arena can assume a basic job in convincing science students' character. This picture can diverge from society to humanity. Numerous people in Asian nations are humiliated to broadcast their ignorance or oppressed execution in science (Steiner \& Mendelovitch, 2017). In China then again, the Confucian ethics have put a high accentuation on learning and students are typical to accomplish greatness in central regimens trains, for example, science (Schoenmakers, Gulmans, Helders \& Van Den Berg, 2001). As opposed to the regularly held in Malaysia viewpoint, accomplishment in subjects isn't fundamental however rather relies upon one's own assurance (Logan, Robinson, Rudisill, Wadsworth \& Morera, 2014). These social adjustments are a case of how the general public and home condition can impact students' attitudes towards science in various nations. This is clear in the aftereffects of the Trend in Mathematics and Science (TIMSS) (2015) as students' perspectives to science shifted significantly across populaces. With explicit reference to Singaporean, Chinese, Thailand and Malaysian students, the previous for the most part communicated an increasingly uplifting science student's attitude. This investigation will communicate to approve such discoveries. It will look at the 14 years old students (Grade 8 ) perspectives' in four selected nations in Singapore, China, Thailand and Malaysia with those of TIMSS (2015).

\section{General Overview of Singaporean, Chinese, Malaysian and Thailand Education Systems}

\section{a) Singapore}

A little country with scarcely any regular assets other than its kin, Singapore has consistently positioned a high incentive on instruction. The strategic Singapore's Ministry of Education (MOE) is to development the eventual fate of the country by supporting its kin. Almost all Singaporean students go to freely subsidized schools. State funded instruction in Singapore is composed and achieved, and means to assist youngsters with creating want and capacities for learning all through life so they may understand their latent capacity, carry on with a full and fulfilling life, and utilize their qualities beneficially to benefit oneself, family, society, and nation. Elementary school training is required, and formal tutoring begins in Grade 1 (Primary 1 ) in the year wherein kids turn age 7. All elementary school students become familiar with a typical national educational program. To manufacture a solid establishment in proficiency and numeracy, English (the language of guidance), native language (Malay, Chinese, or Tamil, contingent upon the student's ethnicity), and science is presented in Grade 3 (Primary 3). Secondary school isn't fundamental, however is finished by about all students in Singapore. At the secondary levels, students take a crack at Express, Normal (Academic), or Normal (Technical) courses of study. These four-to five-year scholastic projects lead to the SingaporeCambridge General Certificate of Education (GCE) Ordinary or Normal Level (O-Level or NLevel) capabilities.

\section{b) China}

In China, a few bodies add to the undertaking of instruction. The Education Bureau (EDB) is responsible for settling on instructive choices, including detailing, creating, and investigating strategies, projects, and enactment from the preprimary to tertiary levels. It directs the employable order of instructive projects. The EDB likewise has the job of watching the 
administrations gave by the University Grants Committee, the Student Financial Assistance Agency, the Examinations and Assessment Authority, the China Council for Accreditation of Academic and Vocation Qualifications, and the Vocational Council. The Curriculum Development Institute (CDI) is a unit of the EDB. It gives proficient initiative and directions educational program improvement joint efforts with neighborhood and global accomplices in the advancement of the nearby school educational program in China. It bolsters schools in the execution of educational program strategies and advancement by giving schools a cognizant, wide, and offset educational plan with adaptable educational program systems and various educational program models, which quickens the improvement of alluring learning conditions and extended learning, and disperses powerful educational program rehearses. In China, neighborhood schools, including government schools, helped schools, Direct Subsidy Scheme (DSS) schools, and tuition based schools, follow a region wide educational plan. In the 2010-2011 scholarly year, balanced mechanism of guidance arrangements were executed at Grade 7 (Secondary 1) and advanced every year to a higher evaluation at the lesser (lower) secondary level. The change arrangements plan to improve the English learning condition to suit the necessities of students and to build student chances to utilize and to be presented to English. Secondary schools may receive English for up to 25 percent of the complete exercise time across subjects, barring the exercise time for English language subjects. On the other hand, secondary schools may dispense appropriate exercise time to the educating of a couple non-language subjects in English. Schools likewise may pick to show a few or all non-language subjects in English, given that the recommended models are met.

\section{b) Malaysia}

In 1983, the Ministry of Education started the Integrated Curriculum for Primary School, which indicates gauges for each degree of primary training. At Level 1 (Primary 1 to 3), the educational program underlines the securing of perusing, composing, and number juggling aptitudes. At Level 2 (Primary 4 to 6), the educational plan is pondered to underscore the dominance of these primary aptitudes and fabricate a solid establishment in science and arithmetic. The science and arithmetic educational programs at the primary level were assessed in 2011, and the reconsidered educational programs have been executed bit by bit, starting with standard 1 student in 2011 (Curriculum Development Division, Ministry of Education Malaysia, 2011). The Integrated Curriculum for Secondary School has been in consequence since 1989. It contains a wide scope of subjects in expressions of the human experience and sciences, just as professional and specialized subjects. The objective of the science educational plan is to manage the cost of students with information and abilities for critical thinking and dynamic in regular day to day existence, guided by virtues, for example, to get ready students to seek after further training in science and innovation and to improve a dependable, dynamic, and dynamic culture with a culture of science and innovation that qualities nature and the salvation of the earth.

c) Thailand

The national government of Thailand incorporates 19 ministries, with the Ministry of Education being liable for the oversight of training. The arrangement of instruction in Thailand can be sorted into three kinds: formal training, non-formal training, and casual training. Thailand's instructive assistance territories incorporate two levels: primary educational service areas and secondary educational service areas. The Institute for the Promotion of 
Teaching Science and Technology (IPST) has been authorized by the Ministry of Education to develop arithmetic and science educational programs at the primary instructive level and to help educating and learning in these two branches of knowledge. In each branch of knowledge, the IPST has suggested learning gauges and comparable student goals. These measures make what students should know and ought to have the option to perform after completing instruction at the primary level. What's more, these learning norms fill in as a vital machine in the instruction framework, as they offer substance and training strategies just as assessment apparatuses.

\section{Research Methodology}

Students' perspectives towards science in selected secondary schools (grade 8) in Singapore, China, Malaysia and Thailand is the main objective in this quantitative research. The study means to look at the attitudes of 14 years of age students towards science. Some evaluations will also be made between the discoveries of this investigation and those of TIMSS (2015) consequence. This will permit the authors to approve and relate these discoveries not simply between Singapore, China, Malaysia and Thailand students yet additionally among male and female of these Asian students. The accompanying exploration addresses will be tended to:

1. What are science students' perspectives from Singapore, China, Malaysia and Thailand associate?

2. What are the perspectives of the Singaporean, Chinese, Malaysian and Thailand students in this investigation relate with their companions in TIMSS (2015)?

\section{Sampling Technique}

The authors were interested in regards to the contrasts between Singaporean, Chinese, Malaysian and Thailand students' exhibitions on worldwide comparison tests. As of late Singaporean and Chinese students have reliably scored in the top band of TIMSS report while Malaysian and Thailand students have been positioned at either side of the normal imprint as showed in Figure 1. Given the relationship between student attitude and accomplishment in science, it was chosen to look at the attitude towards study of a sample of 14 years old students from these countries. 


\section{$8^{\text {th }}$ Grade TIMSS (2003 - 2015)}
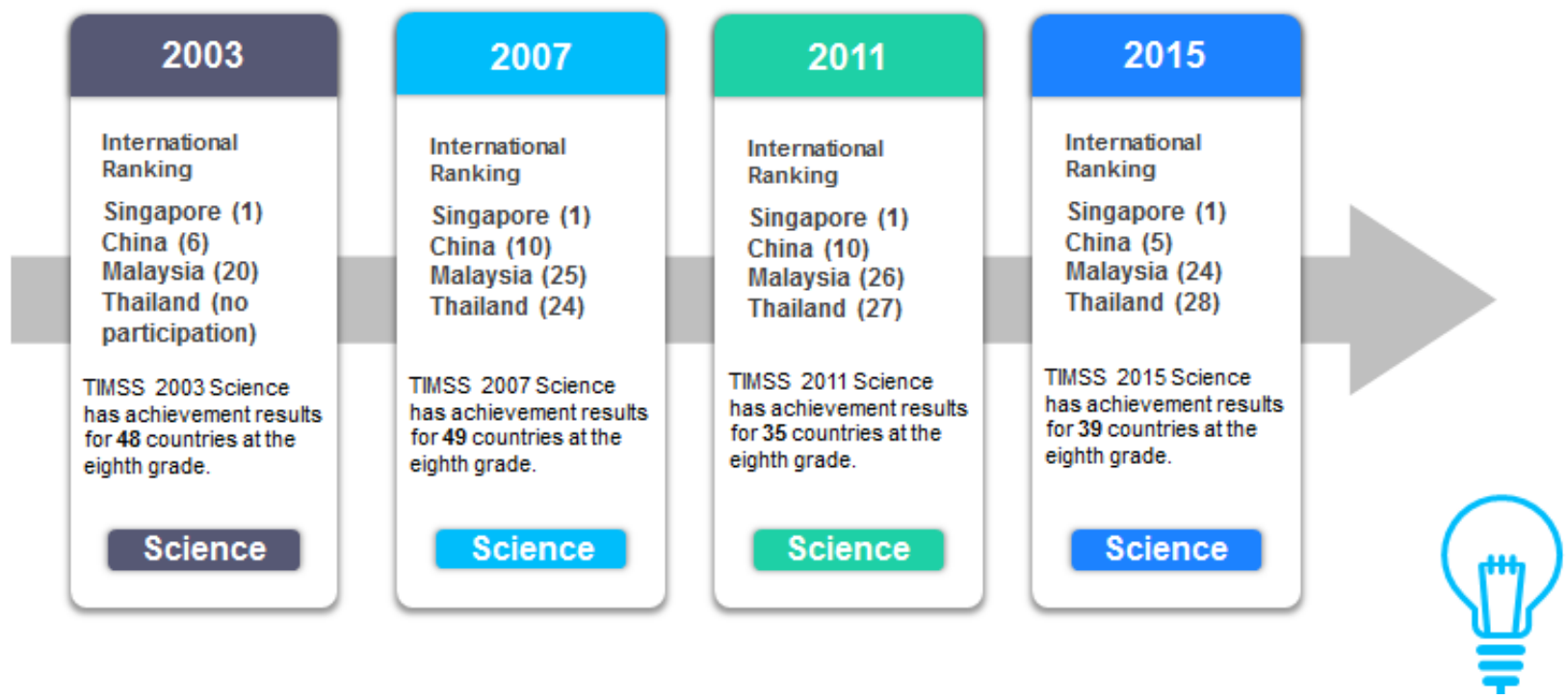

Figure 1: International ranking in science performance of selected countries in TIMSS from

$$
2003-2015
$$

Table 1 show the sample size comprised of 6116 Singaporean students, 4155 Chinese students, 9726 Malaysian students and 6482 Thailand students.

Table 1: Data collection for four selected countries in $8^{\text {th }}$ grade TIMSS 2015

\begin{tabular}{|c|r|r|r|}
\hline Country & Sample & Male & Female \\
\hline Singapore & 6116 & 3138 & 2978 \\
\hline China & 4155 & 2181 & 1974 \\
\hline Malaysia & 9726 & 4711 & 5015 \\
\hline Thailand & 6482 & 2973 & 3509 \\
\hline TOTAL & 26479 & 13003 & 13476 \\
\hline
\end{tabular}

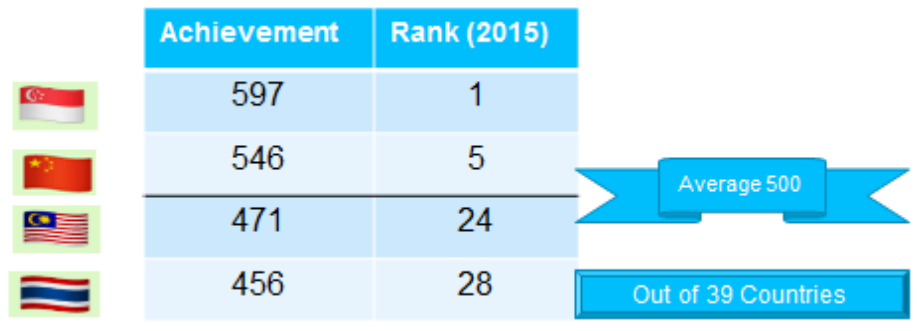

Science student's attitude background data was recorded (age, sexual orientation and nationality). The students were aged between 14 years old and there was an even sex evenness (13003 male students and 13476 female students).

\section{Data Collection}

Throughout the years numerous questionnaire items have been created and used to gauge science student attitude. Attitude was first estimated by perception of real and proposed practices however were viewed as loose because of the potential misinterpretations that could happen (Markley, 1988). The most observable procedure of estimating attitude character has experienced self-report surveys which utilize an assortment of Likert scales (Komorita, 1963). The absolute most notable of these incorporate the Fennema and Sherman (1976) and the Aiken (1974) scales. The authors chose the utilization of TIMSS 2015 instruments since it is a decently simple Likert scale ( 1 to 5 level of agreement) and considers 
contemporary factors, for example, bunch work and reasonable in the instructing and learning of science.

\section{Data Analysis}

The data information for this investigation was gathered in TIMSS 2015. The review comprised of 20 things, and respondents were approached to report the degree to which they concurred or couldn't help contradicting every announcement on a scale of 1 - 5. Fifteen of the statements in the questionnaire were worded toward a providential attitude towards science. Respondents were solicited to show their level from understanding or conflict with each item; 1 = strongly disagree, $2=$ disagree, $3=$ undecided, $4=$ agree, $5=$ strongly agree. There is no adversely worded thing in this set. In this way a high score would demonstrate a progressively ideal attitude towards science. The greatest score that could be accomplished by a respondent was 75 . Missing information was additionally coded to represent addressed inquiries or cases in which at least two answers were circumnavigated. The 15 explanations on the first TIMSS 2015 questionnaire were additionally separated into three factor structures which indicate three attitude segments. They are:

Science Attitude 1 - Effort: Positivity towards learning science in school

This part was comprised of five explanations from the scale (Statements 1, 2, 3, 4 and 5). Model: Statement 1 - I look forward to learning science in school.

Every one of these announcements commonly gave a sign of students' exertion and attitudes toward science in school. The most elevated conceivable score for this segment was 25 .

Science Attitude 2 - Efficacy: Working cooperatively and associated impact

This part was comprised of five articulations from the scale (Statements 6, 7, 8, 9 and 10). Model: Statement 6 - I usually do well in science group assessment.

Every one of these announcements mutually gave a sign of students' adequacy and attitude character towards working cooperatively with others. The most elevated conceivable score for this segment was 25 .

Science Attitude 3 - Belief: Inner sense of spirit

This part was comprised of five explanations from the scale (Statements 11, 12, 13, 14 and 15). Model: Statement 11 - I think learning science will help me in my daily life.

These announcements all things considered gave a sign of students' conviction towards internal feeling of soul in science instruction. The most noteworthy conceivable reading for this part was 25 .

\section{Findings}

Once gathered, the reactions of the 26479 studies were recorded and investigated utilizing Statistical Package for Social Sciences (SPSS) (Version 23.0). A scope of factual investigation was led which encompassed statistical descriptive frequecies and hypothetical significance testing. The Cronbach alpha coefficients computation started the analyses for every attitude character part in all four nations (Table 2) as proven by Brookstein et al. (2011), they permitted the alpha coefficients to be contrasted. The Cronbach alpha coefficients for each of the four nations recommend that a few segments of the scale, especially Attitude 3 - belief nearly didn't have great dependability and inward consistency $(<0.7)$. The authors equally considered the Cronbach alpha coefficients of each example to decide if the internal consistency for the TIMSS 2015 questionnaire scale was especially oppressed for the Singaporean, Chinese, Malaysian or Thailand students. 
Table 2: Reliability test results

\begin{tabular}{|c|c|c|}
\hline Construct & Cronbach alpha & Details \\
\hline Item1- Item30 & 0.720 & Reliable \\
\hline
\end{tabular}

In light of Table 2 it is realized that the Cronbach alpha of these instruments surpasses the estimation of 0.7 . This demonstrates the estimations can give reliable outcomes when estimated on a similar subject. The internal consistency of the scale veered for each attitude in the entirety of the attitude segments yet especially in Attitude 3 - belief where there was an exceptionally low score for Malaysian and Thailand students. This reasons the announcements in every attitude character and especially Attitude 3 - belief were not all estimating a similar primary construct. Besides the distinctive Cronbach alpha coefficients for every attitude items in each sample deduce that the dependability of the scale different on occasion contingent upon whether it is a Singaporean, Chinese, Malaysian or Thailand sample. Results of descriptive statistics found that there was a measurably huge contrast $(t(24584)=$ 23.587, $p=0.000$, two-tailed) between the total overall mean attitude score of the Singaporean (Mean: 2.52, Standard deviation: 0.32), Chinese (Mean: 2.20, Standard deviation: 0.42), Malaysian (Mean: 2.16, Standard deviation: 0.32) and Thailand (Mean: 2.04, Standard deviation: 0.37 ) students.

The reactions to every feedback from independent samples t-tests were recorded and these indicated that there were factually noteworthy contrasts $(p<0.05)$ in the attitude of the selected countries of Singaporean, Chinese, Malaysian and Thailand students in 17 of the 18 articulations from the eighth grade TIMSS 2015 survey. As confirm by the outcomes in Table 3 the Singaporean and Chinese students who took an interest in the investigation listened cautiously to their science instructor, preferred science, were keen on it, were emphatic in their abilities to take care of issues, enjoyed offering their plans to schoolmates yet in addition loved chipping away at their own, fundamentally more than their colleagues (Malaysian and Thailand).

Table 3: Comparative mean which Singaporean and Chinese students differed significantly more than Malaysian and Thailand students

\begin{tabular}{lccccccc}
\hline & Asian Countries & $\begin{array}{c}\text { Attitude } \\
\text { towards } \\
\text { Science }\end{array}$ & $\begin{array}{c}\text { Mean } \\
\text { difference }\end{array}$ & $\begin{array}{c}\text { Std. } \\
\text { Error } \\
\text { differenc } \\
\text { e }\end{array}$ & t & df & $\begin{array}{c}\text { Sig } \\
\text { (2tailed) }\end{array}$ \\
\hline Pair 1 & Belief & -0.007 & 0.008 & -0.910 & $\begin{array}{c}1014 \\
2\end{array}$ & 0.363 \\
Pair 2 & $\begin{array}{c}\text { Singaporean } \\
\text { vs Chinese }\end{array}$ & Effort & -0.052 & 0.007 & -7.563 & $\begin{array}{c}1014 \\
9\end{array}$ & 0.000 \\
Pair 3 & & Efficacy & -0.072 & 0.014 & -5.270 & $\begin{array}{c}1018 \\
7\end{array}$ & 0.000 \\
\hline Pair 4 & & Belief & -0.183 & 0.009 & -20.76 & $\begin{array}{c}1540 \\
9\end{array}$ & 0.000 \\
Pair 5 & $\begin{array}{c}\text { Singaporean } \\
\text { vs Malaysian }\end{array}$ & Effort & -0.024 & 0.005 & -4.741 & $\begin{array}{c}1552 \\
8\end{array}$ & 0.000 \\
Pair 6 & & Efficacy & -0.195 & 0.010 & 19.877 & 1561 & 0.000 \\
\hline
\end{tabular}


INTERNATIONAL JOURNAL OF ACADEMIC RESEARCH IN BUSINESS AND SOCIAL SCIENCES Vol. 11, No. 4, 2021, E-ISSN: 2222-6990 @ 2021 HRMARS

\begin{tabular}{|c|c|c|c|c|c|c|c|}
\hline Pair 7 & & Belief & 0.197 & 0.008 & 26.11 & $\begin{array}{c}1238 \\
0\end{array}$ & 0.000 \\
\hline Pair 8 & $\begin{array}{l}\text { Singaporean } \\
\text { vs Thailand }\end{array}$ & Effort & 0.064 & 0.006 & 10.11 & $\begin{array}{c}1238 \\
1\end{array}$ & 0.000 \\
\hline Pair 9 & & Efficacy & 0.105 & 0.011 & 9.63 & $\begin{array}{c}1248 \\
5\end{array}$ & 0.000 \\
\hline $\begin{array}{l}\text { Pair } \\
10\end{array}$ & & Belief & -0.176 & 0.011 & -16.342 & $\begin{array}{c}1345 \\
3\end{array}$ & 0.000 \\
\hline $\begin{array}{l}\text { Pair } \\
11\end{array}$ & $\begin{array}{l}\text { Chinese vs } \\
\text { Malaysian }\end{array}$ & Effort & 0.029 & 0.006 & 4.531 & $\begin{array}{c}1358 \\
3\end{array}$ & 0.000 \\
\hline $\begin{array}{l}\text { Pair } \\
12\end{array}$ & & Efficacy & 0.267 & 0.012 & 22.887 & $\begin{array}{c}1365 \\
7\end{array}$ & 0.000 \\
\hline $\begin{array}{l}\text { Pair } \\
13\end{array}$ & & Belief & 0.204 & 0.009 & 22.053 & $\begin{array}{c}1042 \\
4\end{array}$ & 0.000 \\
\hline $\begin{array}{l}\text { Pair } \\
14\end{array}$ & $\begin{array}{l}\text { Chinese vs } \\
\text { Thailand }\end{array}$ & Effort & 0.116 & 0.008 & 14.457 & $\begin{array}{c}1043 \\
6\end{array}$ & 0.000 \\
\hline $\begin{array}{l}\text { Pair } \\
15\end{array}$ & & Efficacy & 0.177 & 0.013 & 13.721 & $\begin{array}{c}1053 \\
0 \\
\end{array}$ & 0.000 \\
\hline $\begin{array}{l}\text { Pair } \\
16\end{array}$ & & Belief & 0.380 & 0.009 & 40.911 & $\begin{array}{c}1569 \\
1\end{array}$ & 0.000 \\
\hline $\begin{array}{l}\text { Pair } \\
17\end{array}$ & $\begin{array}{l}\text { Malaysian vs } \\
\text { Thailand }\end{array}$ & Effort & 0.087 & 0.006 & 15.509 & $\begin{array}{c}1581 \\
5\end{array}$ & 0.000 \\
\hline $\begin{array}{l}\text { Pair } \\
18\end{array}$ & & Efficacy & -0.090 & 0.009 & -9.711 & $\begin{array}{c}1595 \\
5\end{array}$ & 0.000 \\
\hline
\end{tabular}

\section{Conclusion}

Significant contrasts in the perspectives of the four chose associates of Singaporean, Chinese, Malaysian and Thailand students towards science have been underlined. An increasingly gritty glance at the outcomes uncovered various positive and negative contentions for approach authors and science teachers in selected countries to be considered. From a Singaporean and Chinese viewpoint, students' uplifting attitudes toward science were skilled. However the concerns of previous reports with respect to principled possibilities were again evident in the discoveries. From a Malaysian and Thailand point of view, student's commitment in the science classroom was undeniably negative. In any case, like the discoveries of TIMSS (2015), this investigation found that significant work in creating positive student's attitude towards science is as yet required. Wan and Lee (2017) found that perspectives can create, alter and change with time, and these discoveries recommend that an accentuation around there would not be fruitless. A few factors, for example, the society and home environment, instructor quality and important encouraging techniques have been found to assume an essential job in building up an inspirational attitude among students. A portion of these components have been addressed in a recent overhaul of the Malaysian optional school science educational program which was changed in January 2020 on a phased basis. It is normal this transformed educational plan will sustain increasingly positive instructing strategies. This is an agreeable result yet dependent on the discoveries of this investigation and attitude towards the subject through advancing the utilizations of science and progressively imaginative TIMSS (2015), more work is required in the extension and supportability of uplifting attitudes if Malaysian and Thailand students are to come in 
accordance with their counterparts (Singaporean and Chinese). This is significant findings given that the learning of science isn't just a subjective test, yet in addition a full of feeling one (Hillman et al., 2016).

\section{Acknowledgement}

The authors would like to acknowledge the financial support and staff of the Universiti Tun Abdul Razak (UNIRAZAK) for their assistance during this study through the UNIRAZAK Research Grant Scheme. The authors likewise might want to thank for the comments and thoughts got from the editors really taking shape of this article were totally prepared for publication.

\section{Corresponding Author}

Azrul Fazwan Kharudin

Graduate School of Business, Universiti Tun Abdul Razak (UNIRAZAK), Malaysia

Email: azrulfazwan@unirazak.edu.my

\section{References}

Allport, W. (1935). Attitudes. In C. A. Murchison (Ed.), A handbook of social psychology. Worcester: Clark University Press.

Astley, J., \& Francis, L. J. (2010). Promoting positive attitudes towards science and religion among sixth-form pupils: dealing with scientism and creationism. British Journal of Religious Education, 32(3), 189-200.

Brookstein, A., Hegedus, S., Dalton, S. Moniz, R., \& Tapper, J. (2011). Measuring Student Attitude in Mathematics Classrooms. Report No. 4, Dartmouth, Kaput Centre for Research and Innovation in STEM Education.

Caleon, I. S., \& Subramaniam, R. (2008). Attitudes towards science of intellectually gifted and mainstream upper primary students in Singapore. Journal of Research in Science Teaching: The Official Journal of the National Association for Research in Science Teaching, 45(8), 940-954.

Dart, B. C., Burnett, P. C., Purdie, N., Boulton-Lewis, G., Campbell, J., \& Smith, D. (2000). Students' conceptions of learning, the classroom environment, and approaches to learning. The Journal of Educational Research, 93(4), 262-270.

DeBellis, V. A., \& Goldin, G. A. (1997). The affective domain in mathematical problem solving. In E. Pehkonen (Eds.), Proceedings of the 21st Conference of the International Group for the Psychology of Mathematics Education, Vol. 2, University of Helsinki, Lahti, Finland, pp. 209-216.

Fennema, E., \& Sherman, J. A. (1976). Fennema-Sherman Mathematics Attitudes Scales: Instruments designed to measure attitudes toward the learning of mathematics by males and females. Catalogue of Selected Documents in Psychology, 6(1), 31.

Hacieminoglu, E. (2016). Elementary School Students' Attitude toward Science and Related Variables. International Journal of Environmental and Science Education, 11(2), 35-52.

Haladyna, T., Shaughnessy, J., \& Shaughnessy, M. (1983). A causal analysis of attitude toward mathematics. Journal for Research in Mathematics Education, 14, 19-29. Hannula, M.S. (2002). Attitude towards Mathematics: Emotions, Expectations and Values. Educational Studies in Mathematics, 49(1), 25-46. 
Hillman, S. J., Zeeman, S. I., Tilburg, C. E., \& List, H. E. (2016). My Attitudes Toward Science (MATS): The development of a multidimensional instrument measuring students' science attitudes. Learning Environments Research, 19(2), 203-219.

Jung, S., \& Siedlecki, K. L. (2018). Attitude toward own aging: Age invariance and construct validity across middle-aged, young-old, and old-old adults. Journal of Adult Development, 25(2), 141-149.

Kharuddin, A. F., \& Ismail, N. A. (2017). Graphing calculator exposure of mathematics learning in a partially technology incorporated environment. EURASIA Journal of Mathematics, Science \& Technology Education, 13(6), 2529-2537.

Komorita, S. S. (1963). Attitude content, intensity, and the neutral point on a Likert scale. The Journal of social psychology, 61(2), 327-334.

Logan, S. W., Robinson, L. E., Rudisill, M. E., Wadsworth, D. D., \& Morera, M. (2014). The comparison of school-age children's performance on two motor assessments: the Test of Gross Motor Development and the Movement Assessment Battery for Children. Physical Education and Sport Pedagogy, 19(1), 48-59.

Ma, Xin. (2001). Participation in Advanced Mathematics: Do Expectation and Influence of Students, Peers, Teachers, and Parents Matter? Contemporary Educational Psychology, 26(1), 132-146.

Markley, F. L. (1988). Attitude determination using vector observations and the singular value decomposition. Journal of the Astronautical Sciences, 36(3), 245-258.

McLeod, D. (1992). Research on affect in mathematics education: A reconceptualization. In D. A. Grouws (Eds.), Handbook of research on mathematics teaching and learning (pp. 575-596). New York: Macmillan.

Miao, C., Humphrey, R. H., \& Qian, S. (2017). A meta-analysis of emotional intelligence and work attitudes. Journal of Occupational and Organizational Psychology, 90(2), 177202.

Mohamed, L., \& Waheed, H. (2011). Secondary Student's Attitude towards Mathematics in a Selected School of Maldives. International Journal of Humanities and Social Science, 1(15): 277-281.

Mohammad, S. M. (2016). Sentiment analysis: Detecting valence, emotions, and other affectual states from text. In Emotion measurement (pp. 201-237). Woodhead Publishing.

Neale, D. C. (1969). The role of attitudes in learning mathematics. The Arithmetic Teacher, 16, 631-640.

Oon, P. T., \& Fan, X. (2017). Rasch analysis for psychometric improvement of science attitude rating scales. International Journal of Science Education, 39(6), 683-700.

Papanastasiou, C. (2000). Effects of attitudes and beliefs on mathematics achievement. Studies in Educational Evaluation, 26, 27-42.

Prendergast, M., \& O'Donoghue, J. (2014). 'Students enjoyed and talked about the classes in the corridors': pedagogical framework promoting interest in algebra. International Journal of Mathematical Education in Science and Technology, 45(6), 795 - 812.

Prendergast, M., \& Hongning, Z. (2016). A comparative study of students attitudes towards mathematics in two different school systems. International Journal for Mathematics Teaching and Learning, 17(2).

Sadruddin, M. M., Khawaja, M., \& Zafar, S. (2017). Attitude Of Prospective Teachers Towards Scienceexploring Teachers Preparedness In The Subject Area Of Science Education At Teacher Education Level In Sindh, Pakistan. Grassroots, 50(3). 
Schoenmakers, M. A. G. C., Gulmans, V. A. M., Helders, P. J. M., \& Van Den Berg, H. M. (2001). Motor performance and disability in Dutch children with haemophilia: a comparison with their healthy peers. Haemophilia, 7(3), 293-298.

Schulz, A., Müller, P., Schemer, C., Wirz, D. S., Wettstein, M., \& Wirth, W. (2018). Measuring populist attitudes on three dimensions. International Journal of Public Opinion Research, 30(2), 316-326.

Steiner, D., \& Mendelovitch, M. (2017). I'm the same teacher": The attitudes of science and computer literacy teachers regarding integrating ICT in instruction to advance meaningful learning. Eurasia Journal of Mathematics, Science and Technology Education, 13(5), 1259-1282.

Summers, R., Wang, S., Abd-El-Khalick, F., \& Said, Z. (2019). Comparing Likert Scale Functionality Across Culturally and Linguistically Diverse Groups in Science Education Research: an Illustration Using Qatari Students' Responses to an Attitude Toward Science Survey. International Journal of Science and Mathematics Education, 17(5), 885-903.

Van Ijzendoorn, M. H., Juffer, F., \& Poelhuis, C. W. K. (2005). Adoption and cognitive development: a meta-analytic comparison of adopted and nonadopted children's IQ and school performance. Psychological bulletin, 131(2), 301.

Vernadakis, N., Avgerinos, A., Tsitskari, E., \& Zachopoulou, E. (2005). The use of computer assisted instruction in preschool education: Making teaching meaningful. Early Childhood Education Journal, 33(2), 99-104.

Wan, Z. H., \& Lee, J. C. K. (2017). Hong Kong secondary school students' attitudes towards science: A study of structural models and gender differences. International Journal of Science Education, 39(5), 507-527.

Widowati, A., Nurohman, S., \& Anjarsari, P. (2017). Developing science learning material with authentic inquiry learning approach to improve problem solving and scientific attitude. Jurnal Pendidikan IPA Indonesia, 6(1).

Woo, Y., \& Reeves, T. C. (2007). Meaningful interaction in web-based learning: A social constructivist interpretation. The Internet and higher education, 10(1), 15-25

Yee, L. S., \& Manap, Y. A. (2018). Attitude Towards Science Among Lower Secondary Students in Johor Bahru. EDUCATUM Journal of Science, Mathematics and Technology (EJSMT), 5(2), 40-46. 